\title{
Pediatri Hemşirelerinin Çocuk Haklarına Yönelik Tutumlarının Belirlenmesi
}

\author{
Dilek Küçük Alemdar ${ }^{1}$, Gamze Yılmaz ${ }^{2 *}$ \\ ${ }^{1}$ Giresun Üniversitesi Sağlık Bilimleri Fakültesi, Ebelik Bölümü, Giresun, Türkiye \\ ${ }^{2}$ Ağrı İbrahim Çeçen Üniversitesi Sağlık Yüksekokulu Hemşirelik Bölümü, Ağrı, Türkiye, \\ dilekucuk@atauni.edu.tr,gamzeyilmaz@live.com \\ Orcid:0000-0002-7275-0666 \\ Orcid:0000-0002-0417-170X \\ *Sorumlu Yazar / Corresponding Author: Gamze Y1lmaz \\ Gönderim Tarihi / Received:06.03.2019 \\ Kabul Tarihi / Accepted: 19.06.2019 \\ DOI: $10.34087 /$ cbusbed.536679
}

\begin{abstract}
$\ddot{O} z$
Amaç: Çocuk haklarına saygıyı öngören bir kültür yaratılmasında çocuklarla birlikte ve çocuklar için çalışan profesyonellerin bu alanda bilgilendirilmesi önemli bir konudur. Bu çalışma, pediatri hemşirelerinin çocuk hakları konusundaki tutumlarını belirlemek amacıyla tanımlayıcı tipte gerçekleştirilmiştir.

Gereç ve Yöntem: Araştırma evrenini, Türkiye'nin doğu bölgesinde bir ilde bulunan hastanelerin pediatri servislerinde çalışan 82 hemşire oluşturmuştur. Çalışmada örneklem seçim yöntemine gidilmemiş, araştırmanın yapıldığı tarihler arasında ulaşılan ve araştırmaya katılmayı gönüllü kabul eden 68 hemşire araştırmanın örneklemine alınmıştır. Araştırmada veri toplama aracı olarak; hemşirelerin demografik, mesleki ve çocuk hakları ile ilgili bilgilerinin değerlendirildiği "Tanıtıcı Bilgi Formu” ve "Çocuk Haklarına Yönelik Tutum Ölçeği”" (ÇHYTÖ) kullanılmıştır.

Bulgular: Hemşirelerin \%83.8'i kadın, \%48.5'i lisans mezunu, \%50'si bekar ve \%83.8'i çocuk sahibi değildir. Hemşirelerin, yaş ortalaması $26.88 \pm 4.87$ yıl, mesleki deneyim süresi ortalaması $6.01 \pm 4.04$ yıl ve pediatri servisinde çalışma süresi 4.25 2.73 yıldır. Hemşirelerin \%79.4'ünün çocuk hakları hakkında bilgi sahibi olduğu, \%76.5'inin ise çocuk haklarının ihlal edildiğini düşündüğü bulunmuştur. Hemşirelerin ÇHYTÖ’den almış oldukları toplam puan ortalaması ise $36.19 \pm 10.19$ 'dir. Hemşirelerin çocuk haklarına yönelik bilgi sahibi olması ile ÇHYTÖ puan ortalaması arasında anlamlı bir ilişki $(\mathrm{p}<0,05)$ saptanmış olup bilgi sahibi olan hemşirelerin daha düşük puan aldıkları yani çocuk haklarına yönelik olumlu tutum gösterdikleri görülmüştür.

Sonuç: Pediatri hemşirelerin çocuk haklarına yönelik olumlu tutum göstermelerine rağmen hemşirelerin büyük çoğunluğunun çocuk haklarına yönelik bilgi sahibi olmadıkları belirlenmiştir. Bu sonuçlar doğrultusunda, pediatri servislerinde çalışan hemşirelerin çocuk hakları konusunda bilgilendirilmesi ve farkındalığın arttırılması için gerekli hizmet içi eğitimlerin verilmesi önerilebilir. Ayrıca hemşirelik eğitimi müfredatında çocuk hakları ile ilgili konulara kapsamlı şekilde yer verilmesi önerilebilir.
\end{abstract}

Anahtar Kelimeler: Çocuk Hakları, Pediatri, Hemşire.

\section{Abstract}

Purpose: In creating a culture that foresees respect towards children's rights, informing professionals that work for children as well as the children themselves is an important topic. This study is conducted as descriptive in order to determine the attitudes of the pediatric nurses towards the subject of children's rights. Materials and Methods: The population of the study was conducted in the hospitals in the eastern Turkey of 82 nurses working in children's services. The sample consisted of 68 nurses who agreed to participate in the study "Descriptive Information Form" and "Attitude Scale Towards Children's Rights" (ASTCR) were used as data collection tools.

Results: $83.8 \%$ of the are women, $48.5 \%$ are graduates with bachelor's degrees, $50.0 \%$ are single, $83.8 \%$ are without a child. Age average of the nurses were $26.88 \pm 4.87$ years, professional experience period averages were $6.01 \pm 4.04$ years and the period for working at the child service was $4.25 \pm 2.73$ years. $79.4 \%$ of the nurses were informed about the rights of children and $76.5 \%$ of them thought that children's rights were violated. They received an average score of $36.19 \pm 10.19$ from the Nurses' ASTCR. There was a significant relationship between nurses 
being knowledgeable and ASTCR score averages, and it was seen that the ones that were knowledgeable received lower scores.

Conclusıon: Although pediatric nurses showed positive attitudes towards children's rights, it was determined that the majority of nurses were not aware of the rights of children. Pediatric nurses may be offered in-service training on children's rights and a wide range of issues related to children's rights in nursing education.

Key words: Children Rights, Pediatric, Nurses.

\section{Giris}

Çocuğun bedensel, zihinsel, sosyal, duygusal ve ahlaki bakımdan özgürlük ve saygınlık içinde, sağlıklı bir gelişim gösterebilmesi için kurallar ile korunan yararları çocuk hakları olarak tanımlanmaktadır [1]. Çocuk hakları her çocuğun gelişip optimal potansiyeline ulaşabildiği, sağlıklı olabildiği, şiddet ve yokluktan uzak, oynayıp öğrenebildiği ortamlarda güven içinde, bakılıp büyütüldüğü bir çocukluğu işaret etmektedir [2]. Çocuk Hakları Sözleşmesi çocukların fiziksel, zihinsel, ruhsal, sosyal ve ahlaki gelişimlerine cevap verebilmek amacıyla, Birleşmiş Milletler Genel Kurulu tarafından 20 Kasım 1989 tarihinde kabul edilerek 2 Eylül 1990 tarihinde yürürlüğe giren çocuklara ilişkin ilk uluslararası sözleşmedir. Türkiye'de dahil olmak üzere yaklaşık 142 ülke sözleşmeyi imzalamış ya da onay ve katılma yoluyla taraf devlet durumuna gelmiştir. Ülkemiz Çocuk Hakları Sözleşmesi'ni 2 Ekim 1995'te uygulamaya başlamıştır. Çocuk Hakları Sözleşmesi ile çocuğun, yaşama, barınma, eğitim, güvenlik, isim hakkı, vatandaşlık, hak ve özgürlükleri, kimlik, kimliğinin korunması, düşünce, vicdan hakk1, inanç özgürlüğü, dernek kurma, özel yaşam dokunulmazlığ 1 , işkenceden korunma, kötü muamele görmeme, cezalandırılmama gibi hakları koruma altına alınmaktadır [3-6]. Sözleşme ayrım gözetmeme, her konuda çocuğun yüksek yararının düşünülmesi, yaşam, gelişme ve katılım haklarını temel almakla birlikte, cinsiyeti, doğum yeri, dini, ailesi veya toplumsal kökeni ne olursa olsun 18 yaşından küçük bütün kişilerin haklarını kapsamaktadır [7].

Sağlıklı nesiller yetiştirilmesinde çocuk sağlı̆̆ ve hastalıkları ile ilgilenen tüm sağlık disiplinlerinin önemli sorumlulukları vardır. Hemşirelerin, çocukların aile ve toplum içinde fiziksel, zihinsel, duygusal ve sosyal yönden sağlıklı büyüme ve gelişmesinde sorumluluğu bulunmaktadır [8]. Çocuk haklarının önemli bir boyutu da çocuklarla birlikte ve çocuklar için çalışan sağlık profesyonellerine bu alanda eğitim verilerek söz konusu hakları mesleki politikalarında, kişisel uygulamalarında, sağlık hizmetlerinin düzenlenmesi ve sunulmasında ve çocuklar için savunma çalışmalarının yürütülmesinde dikkate almalarıdır [9]. Çocuk yaş grubuna her yönüyle uygun kabul edilebilecek bir sağlı hizmeti vermek isteniyorsa öncelikle; çocuğun gelişim basamakları, gelişim basamaklarına göre gereksinimleri, çocuklarla doğru iletişim kurabilme ve tüm bunları kapsayan çocuk hakları hakkında bilgi sahibi olunması gerekir [10].

Dünyada her 5 çocuktan 4'ü beş yaşına gelmeden bir hastane deneyimi yaşamaktadır [11]. Hastalık, çocuk ve ailesinin endişe ve korku yaşamasına neden olmakla birlikte bu süreçte çocuk ve ailesinin güven, sevgi, sayg1 görme, kendini gerçekleştirme gibi temel gereksinimlerinin karşılanmaması, kendilerini güvende hissetmemelerine ve kaygı düzeylerinin artmasına neden olmaktadır [12]. Hemşire, hasta ve yakınlarıyla en yakın ve en yoğun iletişim kuran sağlık ekibi üyesi olması nedeniyle, birey/hastanın ihtiyaçlarını bilme ve hastayı haksızlıklardan korumada da en uygun kişi konumundadır [13]. Pediatri hemşireleri çocukların mümkün olduğunca en iyi sağlık durumlarına ulaşmaları için yalnızca hastalığ 1 tedavi etmenin ötesinde, onların en iyi sağlık durumuna kavuşma hakk1 önündeki engellerin aşılmasında çocuk hakları perspektifinden bakarak belirleyici rol alabilirler [8]. Bu kapsamda pediatri hemşiresinin; çocuğun haklarını savunma, çocuk ve ailesine hasta ve çocuk hakları hakkında bilgi verme, ailenin ve çocuğun haklarını kavramasını sağlama, sağlık sistemi içinde çocuk haklarının yeri ve kullanımı, çocuk haklarının ihlal edildiği durumlarda çocuğun haklarını savunma, çocuğu ve aileyi bakım ve tedavi hakkında bilgilendirme, çocuk ve ailenin mahremiyetini koruma, onların duygularını anlayarak empati kurma, geleneksel ve kültürel özelliklerini de göz önünde bulundurarak bakım yaklaşımlarını gerçekleştirme sorumluluğu bulunmaktadır $[1,14]$. Profesyonel pediatri hemşireleri bakım verirken eğitim, danışmanlık, duygusal destek sağlamak, çocuklar için en iyi eylemi ve bilgilendirilmiş seçimleri yapmada çocuk ve aileye yardım ederek savunuculuk yapmak ve onların haklarını korumak gibi birçok rolü bir arada gerçekleştirmektedir. Bu nedenle, bütün bu rollerini iyi kavraması, uygulamaya yansıtma becerisini kazanması ve geliştirmesi çocuk ve ailenin dolayısıyla toplum sağlığının korunması ve geliştirilmesi için oldukça önemlidir [14-17].

Çocukların içinde bulunduğu fiziksel, ekonomik ve sosyal ortamlar onların refahı üzerinde önemli bir etkiye sahiptir [8]. Çocuk haklarının çocukların ve ailelerin sağlığı ve refahı açısından taşıdığı önem ve anlam vurgulanmalı, çocukluk dönemi hastalıklarına ve ölümlerine, bunların yol açtığı sonuçlara ilişkin analizlerde çocuk hakları boyutu da dikkate alınmalıdır. $\mathrm{Bu}$ bilgilerden yola çıkarak pediatri hemşirelerinin çocuk haklarına yönelik tutumları ve bu tutumlarını etkileyen faktörleri belirlemek amacıyla çalışmamız gerçekleştirilmiştir.

\section{Gereç ve Yöntem}

2.1. Araştırmanın Tipi, Evreni ve Örneklemi: Çalışma tanımlayıcı ve kesitsel nitelikte bir araştırmadır. Araştırma evrenini, çalışmanın yapıldığ tarihler arasında Türkiye'nin doğu bölgesinde bir ilde 
bulunan hastanelerin pediatri servislerinde çalışan 82 hemşire oluşturmuştur. Çalışmada örneklem seçim yöntemine gidilmemiş, araştırmanın yapıldığı tarihler arasında ulaşılan ve araştırmaya katılmayı gönüllü kabul eden 68 hemşire araştırmanın örneklemine alınmıştır. Araştırmada veri toplama aracı olarak; hemşirelerin demografik, mesleki ve çocuk hakları ile ilgili bilgilerinin değerlendirildiği "Tanıtıcı Bilgi Formu" ve "Çocuk Haklarına Yönelik Tutum Ölçeği” (ÇHYTÖ) kullanılmıştır.

2.2. Verilerin Toplanması: Hemşirelere çalışmanın amacı açıklanarak sözel izinleri alındıktan sonra, formlar çalışmaya katılmayı kabul eden hemşirelere hemşire odasında yaklaşık 10-15 dakika süren yüz yüze görüşme yöntemi ile araştırmacılar tarafından uygulanmıştır. Araştırmanın verileri, araştırmaya katılan hemşirelerin demografik, mesleki ve çocuk hakları ile ilgili bilgilerinin değerlendirildiği "Tanıtıcı Bilgi Formu" ve "Çocuk Haklarına Yönelik Tutum Ölçeği" (ÇHYTÖ) kullanılarak toplanmıştır.

2.2.1. Tanıtıcı Bilgi Formu: Veri toplamak için, araştırmacılar tarafından hazırlanan toplam 17 sorudan oluşan anket formu kullanıldı. Bu formda demografik veriler çocuk hasta haklarına yönelik hazırlanmış sorular (yaş, eğitim düzeyi, medeni durum, çocuk sahibi olma, çalışma süresi, çocuk hasta hakları konusunda bilgisi sahibi olma ve bu konuyla ilgili bir problemle karşılaşıp karşılaşmadığı gibi) yer aldı.

2.2.2. Çocuk Haklarına Yönelik Tutum Ölçeği: Hemşirelerin çocuk haklarına ilişkin tutumlarını belirlemek amacıyla 2006 yılında Karaman Kepenekçi tarafından geliştirilen Çocuk Haklarına Yönelik Tutum Ölçeği (ÇHYTÖ) kullanıldı. 5'li likert formdaki ölçekte çocukların yaşamsal, gelişimsel, korunma ve katılım haklarına ilişkin 22 madde bulunmaktadır. Bu ifadeler için "Tamamen Katılıyorum", "Katılıyorum", "Kararsızım", "Katılmıorum" ve "Tamamen Katılmıyorum" tepki seçenekleri bulunmaktadır. İfadelere verilen tepkiler aynı sırayla $1,2,3,4$ ve 5 olarak puanlanmakta olup, ölçekten alınan puanın yüksek olması olumsuz tutumu göstermektedir. Ölçekteki ifadelerin 19'u olumlu, 3'ü olumsuzdur. Olumsuz ifadelere (2. 14. ve 15 . maddeler) verilen tepkiler ters puanlandı. Ölçekten alınacak en düşük puan 22 ve en yüksek puan ise 110 'idi. Ölçekten alınacak en düşük puan 22 ve en yüksek puan ise 110'dur. Karaman Kepenekçi (2006) ölçeğin geçerliliğine ve güvenilirliğine ilişkin yaptığı çalışma sonucunda, Cronbach Alpha iç tutarlılık katsayısının 85 olarak belirlendiğini ifade etmiştir [18].

2.3. İstatiksel Analiz: Analizler Windows Statistical Package for Social Sciences (SPSS) 21,0 programında yapılmıştır. Çalışma verileri değerlendirilirken tanımlayıc1 istatistiksel metotların (sayı, yüzde, ortalama, standart sapma) yanı sıra ÇHYTÖ puanının gruplar arası karşılaştırmalarında Kruskal Wallis Test ve Mann Whitney U testi kullanılmıştır. Yaş, mesleki deneyim ve pediatri servisinde çalışma süresi ile ÇHYTÖ puanı arasında ilişki analizi için Pearson's korelasyon katsayısı kullanılmıştır. Sonuçlar \% 95'lik güven aralığında, anlamlılık $\mathrm{p}<0.05$ düzeyinde değerlendirilmiştir.

2.4. Araştırmanın Etik Boyutu: Araştırma için Ağrı İbrahim Çeçen Üniversitesi Bilimsel Araştırmalar Etik Kurulu'ndan (95531838-900 sayılı yazı) ve İl Sağlık Müdürlüğü'nden yazılı izin alınmıştır. Araştırmaya katılımın gönüllülük esasına dayandığı ve verilerin başka bir amaçla kullanılmayacağı sağlık çalışanlarına belirtilmiş, araştırmaya gönüllü olan hemşireler dahil edilmiştir. Hemşirelere çalışmanın amacı açıklanarak, herhangi bir zamanda katılım olurunu geri çekme hakkına sahip olduğu ile ilişkili bilgi verilmiştir. Sözlü izinleri alınıp ve daha sonra anket formu uygulanmıştır. Formlar uygulanmadan önce Helsinki Deklarasyonu ilkelerine uyulmuştur.

\section{Bulgular ve Tartışma}

Araștırma kapsamına alınan pediatri hemşirelerinin \%83,8'i kadın, \%48,5'i lisans mezunu, \%50'si bekar ve $\% 83,8$ 'i çocuk sahibi değildir. Hemşirelerin, yaş ortalamas1 $26.88 \pm 4.87$ y1l, mesleki deneyim süresi ortalaması $6.01 \pm 4.04$ y1l ve pediatri servisinde çalışma süresi 4,25 $\pm 2,73$ yıldır. Araştırmadaki hemşirelerin çocuk hakları hakkındaki görüşleri incelendiğinde \%79.4'ünün konu ile ilgili bilgi sahibi olduğu, \%76.5'inin çocuk haklarının ihlal edildiğini düşündüğü, \%98.2'si ise çocuk hakları konusunda çocukların yeterince bilinçlendirilmediklerini ifade etmişlerdir (Tablo 1).

Hemşirelerin ÇHYTÖ toplam puan ortalaması 36.19 \pm 10.19 'dur. Hemşirelerin cinsiyeti, medeni durumu, çocuk sahibi olması ve eğitim düzeyi ile ÇHYTÖ puan ortalamaları arasında anlamlı ilişki bulunmamıştır $(p>0.05)$. Hemşirelerin yaşı ile ÇHYTÖ puan ortalamaları arasında anlamlı ilişki olduğu saptanmıştır $(\mathrm{p}<0.05)$. Ayrıca yapılan korelasyon analizinde hemşirelerin yaş ortalaması ile ÇHYTÖ puan ortalamaları arasında anlamlı ilişki belirlenmiştir ( $\mathrm{r}=$ 0.252; $\mathrm{p}=0.038$ ). Ancak hemşirelerin mesleki deneyim süresi ve çocuk servisinde çalışma süresi ile ÇHYTÖ puan ortalamaları arasında anlamlı ilişki saptanmamıştır ( $p>0.05$ ). Hemşirelerin çocuk haklarına yönelik bilgi sahibi olması ile ÇHYTÖ puan ortalaması arasında anlamlı ilişki olup bilgi sahibi olanların daha düşük puan aldıkları yani çocuk haklarına yönelik olumlu tutum gösterdikleri belirlenmiştir $(\mathrm{p}<0.05)$ (Tablo 2).

Pediatri hemşiresi; çocuk ve ailesi ile olan iletişimini çocuk yararına, yardım amaçlı kurmalı ve bu çerçevede yürütmelidir. Çocuk ve ailesinin fiziksel, duygusal, zihinsel ve sosyal gereksinimlerinin farkında olunmalı, bakımı bu gereksinimler doğrultusunda planlanmalıdır. Pediatri hemşiresinden çocuğun gelişimsel özelliklerini daima hatırlaması, çocuk hakları konusunda daha duyarlı olması beklenmektedir [19-20]. Pediatri hemşiresinin savunuculuk rolü için bilmesi gereken konuların temelinde yer alan hasta haklarında; çocuk hemşiresi çocuğun optimum fiziksel ve duygusal iyiliği için hemşirelik uygulamalarına rehberlik eden 
Uluslararası Çocuk Hakları Beyannamesi'ni esas almalıdır [16]. Pediatri hemşirelerinin çocuk haklarına yönelik tutumlarının değerlendirildiği çalışmamız sonucunda hemşirelerin ÇHYTÖ toplam puan ortalaması 36.19 \pm 10.19 'dur. Ölçekten alınan en düşük puan 22, en yüksek puan 110'dur. Ölçekten alınan düşük puan çocuk haklarına yönelik olumlu tutumu göstermektedir.

Tablo 1. Hemşirelerin demografik, mesleki ve çocuk hakları ile ilgili bilgi durumları

\begin{tabular}{|c|c|c|c|c|c|}
\hline ÖZELLİKLER & $\mathbf{N}$ & $\%$ & ÖZELLİKLER & $\mathbf{N}$ & $\%$ \\
\hline $\begin{array}{l}\text { Yaş } \\
19-25 \\
26-32 \\
33-39\end{array}$ & $\begin{array}{l}32 \\
30 \\
6\end{array}$ & $\begin{array}{l}47.1 \\
44.1 \\
8.8\end{array}$ & $\begin{array}{l}\text { Eğitim düzeyi } \\
\text { Lise } \\
\text { Ön lisans } \\
\text { Lisans } \\
\text { Lisansüstü }\end{array}$ & $\begin{array}{l}18 \\
13 \\
33 \\
4\end{array}$ & $\begin{array}{l}26.5 \\
19.1 \\
48.5 \\
5.9\end{array}$ \\
\hline $\begin{array}{l}\text { Cinsiyet } \\
\text { Kadin } \\
\text { Erkek }\end{array}$ & $\begin{array}{l}57 \\
11\end{array}$ & $\begin{array}{l}83.8 \\
16.2\end{array}$ & $\begin{array}{l}\text { Medeni durum } \\
\text { Bekar } \\
\text { Evli }\end{array}$ & $\begin{array}{l}34 \\
34\end{array}$ & $\begin{array}{l}50.0 \\
50.0\end{array}$ \\
\hline $\begin{array}{lll}\text { Çocuk } & \text { Haklarına } & \text { yönelik } \\
\text { bilgisi } & & \\
\text { Var } & & \\
\text { Yok } & & \\
\end{array}$ & $\begin{array}{l}54 \\
14 \\
\end{array}$ & $\begin{array}{l}79.4 \\
20.6 \\
\end{array}$ & $\begin{array}{l}\text { Çocuk haklarının ihlal edildiğini } \\
\text { Düşünen } \\
\text { Düşünmeyen }\end{array}$ & $\begin{array}{l}52 \\
16 \\
\end{array}$ & $\begin{array}{l}76.5 \\
23.5 \\
\end{array}$ \\
\hline $\begin{array}{l}\text { Çocuk hasta hakları ile ilgili } \\
\text { sorunla } \\
\text { Karşılaşan } \\
\text { Karşışmayan }\end{array}$ & $\begin{array}{l}15 \\
53\end{array}$ & $\begin{array}{l}22.1 \\
77.9\end{array}$ & $\begin{array}{ll}\text { Çocuk hakları } & \begin{array}{r}\text { konusunda } \\
\text { yetişkinler }\end{array} \\
\text { bilinçlendiriliyor mu? } & \\
\text { Evet } & \\
\text { Hayır } & \end{array}$ & $\begin{array}{l}3 \\
65\end{array}$ & $\begin{array}{l}1.8 \\
98.2\end{array}$ \\
\hline \multicolumn{6}{|c|}{$\begin{array}{ll}\text { Yaş }(\mathrm{Ort} \pm \mathrm{SS}) & 26.88 \pm 4.87(\min =19, \max =39)\end{array}$} \\
\hline \multicolumn{2}{|l|}{ Mesleki Deneyim Süresi (Ort \pm SS) } & $6.01 \pm 4.04$ & $(\min =1, \max =20)$ & & \\
\hline \multicolumn{2}{|c|}{ Çocuk Servisinde Çalışma Süresi (Ort \pm SS) } & $4.25 \pm 2.73$ & $(\min =1, \max =11)$ & & \\
\hline
\end{tabular}

$\mathrm{Bu}$ bağlamda çalışmamıza katılan pediatri hemşirelerin çocuk haklarına yönelik olumlu tutum gösterdikleri söylenebilir. Aldemir ve Çiğdem'in (2014) çalışmasında hemşirelik yüksekokulu öğrencilerinin ÇHYTÖ'den aldıkları puan 22 ile 93 arasında değişmekte olup, ortalamasının $29,88 \pm 12,24$ olduğu görülmüştür [21].

Çalışmamızda, hemşirelerin yaşı ile ÇHYTÖ puanları arasında istatistiksel olarak anlamlı bir ilișki bulunmuştur $(\mathrm{p}<0.05)$ (Tablo 2). Karaman Kepenekçi ve Baydık'ın (2009) zihin engelliler öğretmen adaylarının çocuk haklarına ilişkin tutumlarını incelediğ araştırmalarında yaş ile çocuk haklarına ilişkin tutum arasında pozitif yönde anlamlı bir ilişki olduğu bulunmuştur [3]. Aldemir ve Çiğdem (2014) ile Merey’in (2013) çalışmalarında yaş ile çocuk haklarına ilişkin tutum arasında ilişki olmadığ $[21,22]$. Çalışmamız Karaman Kepenekçi ve Baydık'ın (2009) çalışması ile benzerlik göstermektedir [3]. Yaşın artışının çocuk haklarına ilişkin tutumları olumlu olarak etkilediği söylenebilir.

Çalışmamızda, cinsiyete göre ÇHYTÖ puan ortalamaları arasında istatiksel olarak anlamlı farklılık saptanmamıştır ( $>00.05$ ) (Tablo 2). Karaman-Kepenekçi ve Baydık (2009) araştırmalarında cinsiyetin zihin engelliler öğretmenliği programına kayıtlı öğrencilerin çocuk haklarına ilişkin tutumları üzerinde etkisi olmadığını bulmuşlardır [3]. Literatür incelendiğinde kadınların erkeklere göre çocuk haklarına ilişkin daha olumlu bir tutum gösterdikleri bulunmuştur [18,21,23,24]. Merey (2013) ve Kaya (2011) çalışmalarında erkek öğretmen adaylarının kadın öğretmen adaylarına göre çocuk haklarına karşı daha olumlu bir tutuma sahip olduğunu bulmuştur [22,25]. İlgili araştırmaların sonuçları cinsiyet değişkenine yönelik birbirinden farklı sonuçlara ulaşıldığını ortaya çıkarmaktadır. Dolayısıyla cinsiyetin çocuk haklarına yönelik tutumlarının temel belirleyicisinin olmadığ söylenebilir.

Çalışmamızda, hemşirelerin çocuk haklarına yönelik bilgi sahibi olması ile ÇHYTÖ puan ortalaması arasında anlamlı ilişki olup bilgi sahibi olanların çocuk haklarına yönelik olumlu tutum gösterdikleri belirlenmiştir $(p<0.05) \quad$ (Tablo 2). Literatür incelendiğinde, çocuk hakları konusundaki bilgilendirmenin çocuk haklarına yönelik tutumları olumlu etkilediğine ya da etkilemediğine ilişkin bulgular göze çarpmaktadır. Özellikle insan hakları ya da çocuk haklarına ilişkin ders almanın öğrencilerin çocuk haklarına ilişkin tutumlarını olumlu yönde etkilediği bilinmektedir [3,18]. Kahriman ve arkadaşları (2016) pediatrik yaş grubuna sağlık hizmeti sunan ebe ve hemşirelerin çocuk hasta hakları konusundaki düşüncelerini inceledikleri çalışmalarında hemşire ve ebelerin \%60.8'inin çocuk hasta hakları konusunda eğitim almadığını belirtmiştir [26]. Yine çocukla ilgilenen diğer önemli bir disiplin olan öğretmenler üzerinde yapılan çalışmalardan Uçuş'un (2009) yaptığı çalışmada, öğretmen ve okul yöneticileri ile yapılan görüşmeler sonucunda, öğretmenlerin ve okul yöneticilerinin çocuk hakları konusunda yeterince bilgiye sahip olmadıkları açıklanmıştır [27]. Bu bulgular bizim sonuçlarımızı destekler niteliktedir. Aldemir ve Çiğdem'in (2014) 
çalışmasında ise hemşirelik öğrencilerinin çocuk haklarına yönelik bilgi sahibi olmaları ile çocuk haklarına yönelik tutumları arasında anlamlı fark olmadığı belirtilmiştir [21]. Fazıloğlu'nun (2007) yaptığ 1 araştırmada ise; öğretmen ve yöneticilerin çocuk haklarını kavramış oldukları açıklanmıştır [28].

Tablo 2. Hemşirelerin Demografik, Mesleki ve Çocuk Haklarına Yönelik Özellikleri İle ÇHYTÖ Genel Puan Ortalamalarının Karșılaștırılması

\begin{tabular}{|c|c|c|c|c|}
\hline ÖZELLİKLER & $\mathbf{N}$ & $\%$ & Ort \pm SS & $\begin{array}{c}\text { Test } \\
\text { p değeri }\end{array}$ \\
\hline $\begin{array}{l}\text { Yaş } \\
19-25 \\
26-32 \\
33-39\end{array}$ & $\begin{array}{c}32 \\
30 \\
6\end{array}$ & $\begin{array}{l}47.1 \\
44.1 \\
8.8\end{array}$ & $\begin{array}{c}32.71 \pm 8.74 \\
39.40 \pm 11.23 \\
38.66 \pm 6.31\end{array}$ & $\begin{aligned} K W= & 7.091 \mathbf{p}<\mathbf{0 . 0 5} \\
(\mathbf{0 . 0 2 9 )} & \end{aligned}$ \\
\hline $\begin{array}{l}\text { Cinsiyet } \\
\text { Kadın } \\
\text { Erkek }\end{array}$ & $\begin{array}{l}57 \\
11\end{array}$ & $\begin{array}{l}83.8 \\
16.2\end{array}$ & $\begin{array}{c}35.89 \pm 10.31 \\
37.72 \pm 9.83\end{array}$ & $\begin{array}{l}\text { MWU }=272.00 \\
p>0.05(0.489)\end{array}$ \\
\hline $\begin{array}{l}\text { Eğitim düzeyi } \\
\text { Lise } \\
\text { Ön lisans } \\
\text { Lisans } \\
\text { Lisansüstü }\end{array}$ & $\begin{array}{c}18 \\
13 \\
33 \\
4\end{array}$ & $\begin{array}{c}26.5 \\
19.1 \\
48.5 \\
5.9\end{array}$ & $\begin{array}{l}39.75 \pm 13.93 \\
37.69 \pm 6.78 \\
37.24 \pm 11.79 \\
32.38 \pm 7.65\end{array}$ & $\begin{aligned} \mathrm{KW}= & 3.128 \mathrm{p}>0.05 \\
& (0.342)\end{aligned}$ \\
\hline $\begin{array}{l}\text { Medeni durum } \\
\text { Bekar } \\
\text { Evli }\end{array}$ & $\begin{array}{l}34 \\
34\end{array}$ & $\begin{array}{l}50.0 \\
50.0\end{array}$ & $\begin{array}{c}39.35 \pm 11.03 \\
33.07 \pm 8.27\end{array}$ & $\begin{array}{l}\text { MWU }=384.00 \\
p>0.05(0.171)\end{array}$ \\
\hline $\begin{array}{l}\text { Çocuk sahibi olma durumu } \\
\text { Var } \\
\text { Yok }\end{array}$ & $\begin{array}{l}11 \\
57\end{array}$ & $\begin{array}{l}16.2 \\
83.8\end{array}$ & $\begin{array}{c}36.18 \pm 7.67 \\
36.19 \pm 10.66\end{array}$ & $\begin{array}{l}\text { MWU }=291.00 \\
p>0.05(0.708)\end{array}$ \\
\hline $\begin{array}{l}\text { Çocuk Haklarına yönelik bilgisi olma } \\
\text { Evet } \\
\text { Hayır }\end{array}$ & $\begin{array}{l}54 \\
14\end{array}$ & $\begin{array}{l}79.4 \\
20.6\end{array}$ & $\begin{array}{c}35.72 \pm 9.91 \\
38.00 \pm 11.40\end{array}$ & $\begin{array}{l}\text { MWU: } 135.50 \\
\mathbf{p}<\mathbf{0 . 0 5}(\mathbf{0 . 0 3})\end{array}$ \\
\hline $\begin{array}{l}\text { Çocuk haklarının ihlal edildiğini düşünme } \\
\text { Evet } \\
\text { Hayır }\end{array}$ & $\begin{array}{l}52 \\
16\end{array}$ & $\begin{array}{l}76.5 \\
23.5\end{array}$ & $\begin{array}{l}36.44 \pm 10.26 \\
35.37 \pm 10.23 \\
\end{array}$ & $\begin{array}{l}\text { MWU:392.30 } \\
\mathrm{p}>0.05(0.086)\end{array}$ \\
\hline $\begin{array}{l}\text { Çocuk hasta hakları ile ilgili sorunla } \\
\text { Karşılaşan } \\
\text { Karşışmayan }\end{array}$ & $\begin{array}{l}15 \\
53\end{array}$ & $\begin{array}{l}22.1 \\
77.9\end{array}$ & $\begin{array}{c}35.71 \pm 9.61 \\
36.30 \pm 10.08\end{array}$ & $\begin{array}{l}\text { MWU: } 401.50 \\
\mathrm{p}>0.05(0.106)\end{array}$ \\
\hline $\begin{array}{l}\text { Toplam } \\
\text { ÇHYTÖ Toplam Puan Ortalaması (Ort } \pm \text { SS) } \\
\end{array}$ & $\frac{68}{36}$ & $\begin{array}{l}100.0 \\
0.19\end{array}$ & \multicolumn{2}{|c|}{$(\min =22, \max =71)$} \\
\hline
\end{tabular}

\section{Sonuc}

Çalışmamızın sonucunda pediatri hemşirelerin ÇHYTÖ’den düşük puan aldıkları yani çocuk haklarına yönelik olumlu tutum gösterdikleri saptanmıştır. Hemşirelerin çoğu çocuk haklarına yönelik bilgi sahibi olduklarını belirtmiş olup bilgi sahibi olanların anlamlı düzeyde daha olumlu çocuk haklarına yönelik tutum gösterdikleri belirlenmiştir. Bu sonuçlar doğrultusunda öneriler:

- Çocukla çalışan hemşirelerin hizmet içi eğitim programlarına çocuk hakları ile ilgili konular yerleştirilmelidir. Çocuk hakları ile ilgili gerekli eğitimlerin verilerek çocukların yüksek yararı için en uygun koşullarda ve kalitede sağlik hizmeti almaları sağlanabilir. Bu amaçla eğitim programları hazırlanarak bütün sağlık profesyonellerine eğitim verilebilir.

- Hemșirelik eğitimi müfredatında çocuk hakları ile ilgili konular kapsamlı şekilde yer almalı ve çocuk hakları temasını da içerecek şekilde ders içerikleri zenginleştirilmelidir.

- Ülkemizdeki hastanelerin "Çocuk Dostu Hastane" şartlarını karşılayabilmesi için çalışma ve düzenlemeler yapılarak sonrasında "Bebek Dostu Hastane" projesinde olduğu gibi denetimler yapılabilir.

- Çocuk hakları konusunda tüm sağlık çalışanlarına, ebeveynlere, çocukla ilgilenen tüm bireylere ve topluma yönelik eğitim programları ve seminerler düzenlenmelidir.

- Dünyada ve ülkemizde çocuk hakları ve sağlık profesyonelleri ile ilgili araştırmalar son derece kısıtlıdır. Bu alanda yapılacak yeni çalışmalar çocuklar adına olumlu gelişmeler için yol gösterici olabilir.

- Daha büyük ve farklı çalışma grupları ile yürütülecek olan benzer çalışmalar çocuk hakları ile ilgili eğitimin gerekliliğini daha açık bir şekilde ortaya koyabilir. 


\section{Referanslar}

1. Akyüz E. Ulusal ve uluslararası hukukta çocuğun haklarının ve güvenliğinin korunması. Ankara: MEB, 2000:4.

2. Polat $\mathrm{O}$, Kayabeyoğlu İ, Ağrıtmış H. Çocuk gelişimine çocuk hakları açısından yaklaşım. Çocuk Forumu Dergisi. 2001;4 (34):52-61.

3. Karaman Kepenekçi Y, Baydık B. Zihin Engelliler Öğretmen Adaylarının Çocuk Haklarına İlişkin Tutumlar. Ankara Üniversitesi Eğitim Bilimleri Fakültesi Dergisi. 2009, 42(1): 329- 350 .

4. Washington F. 5-6 Yaș Grubu Cocuklarına Uygulanan Aile Katılımlı Çocuk Hakları Eğitimi Programının Etkinliğinin İncelenmesi. Yüksek Lisans Tezi, Marmara Üniversitesi Eğitim Bilimleri Enstitüsü İlköğretim Anabilim Dalı Okul Öncesi Öğretmenliği Bilim Dalı, İstanbul, 2010.

5. Landstown G. Children's Rights and Domestic Violence. Child Abuse Review. 2000; 9: 416- 426.

6. Resmi Gazete. 27.01.1995 Tarih ve 22184 Sayılı.

7. Cılga A. Çocuk Hakları Eğitimi. Milli Eğitim Dergisi. 2001, 151 .

8. Yurdakök K. Uluslararası Çocuk Hakları Sözleșmesi. Katkı Pediatri Dergisi. 2003; 25(1): 37- 42.

9. Örün E, Tatlı MM. Birleşmiş Milletler Çocuk Haklar Sözleşmesi'ne Göre Türk Çocuklarının Sağlık ve Sosyal Hakları Açısından Durumu. Yeni Tip Dergisi. 2012;29(3):132-137.

10. Kurt G. Yataklı sağlık kuruluşlarında çocuk ile ilgili sağlık hizmetlerinin çocuk hakları sözleşmesine uygunluğunun ve sağlık profesyonellerinin çocuk hakları konusundaki farkındalık ve tutumlarının değerlendirilmesi (Tıpta uzmanlık tezi). Kırıkkale Üniversitesi Tıp Fakültesi, Kırıkkale, 2012.

11. Tombul K. Çocuk Cerrahisi Hastalarının ve Anne-Babaların Klinik Ortamdan ve Sağlık Bakım Ekibinden Beklentilerinin Belirlenmesi. Marmara Üniversitesi Sağlık Bilimleri Enstitüsü, Yüksek Lisans Tezi, İstanbul, 2003.

12. Goldhagen J. Children's Rights and the United Nations Convention on the Rights of the Child. Pediatrics Vol. 2003; $742-745$.

13. Ulmer BC. President's message: Professional advocacy. AORN Journal, 2000;72(1): 9-11.

14. Ardahan M. Hemșirelerin savunuculuk rolü. Cumhuriyet Üniversitesi Hemşirelik Yüksekokulu Dergisi, 2003:7(2): 23 27.

15. Ball JW, Bindler RC, Cowen KJ. Child Health Nursing: Partnering with Children and Families/ Nurse's Role in Care of The Child: Hospital, Community Settings, And Home Advote. 2nd ed., Pearson Education, New Jersey, 2010: 1-30.

16. Wong DL, Hockenberry M. Wong's Essentials of Pediatric Nursing Role of the Pediatric Nursing: Family Advocacy. 7th ed., Mosby, An Affiliate of Elsevier Science, St. Louis. 2005.
17. Özakar Akça S, Gözen D, Cocuk Hemșiresinin Savunucu Rolü F.N. Hem. Derg. 2013;21(3): 213-218.

18. Karaman Kepenekci Y. A study of university students attitudes towards children's rights in Turkey. The International Journal of Children's Rights. 2006;14:307-319.

19. Bowden V, Greenberg C. Pediatric Nursing Procedures. 1st ed.,Williams \& Wilkins, Newyork. 2003.

20. Çavuşoğlu H. Çocuk Sağlığı Hemşireliği. 8. basım, Cilt 2 , Dizgi Baskı, Ankara. 2004.

21. Yılmaz Aldemir E, Çiğdem Z. Hemşirelik Yüksekokulu Ögrencilerinin Çocuk Hakları Konusundaki Tutumlarının Belirlenmesi (yüksek lisans tezi). İstanbul, Bilim Üniversitesi, 2014.

22. Merey Z. Sosyal Bilgiler Öğretmen Adaylarının Çocuk Haklarına Karşı Tutumları. Eğitimde Kuram ve Uygulama. 2013, 9(3): 243- 253.

23. Değirmenci T. Öğretmen Adaylarının Çocuk Haklarına İlişkin Tutumlarının İncelenmesi. 20. Ulusal Eğitim Bilimleri Kurultayı Bildiri Özeti. Burdur, 2011.

24. Leblebici H, Çeliköz N. Prospective teachers' attitudes towards children rights. International Journal of Social Sciences and Education Research. 2017;3(1):307-318.

25. Kaya SA. Öğretmen Adaylarının Çocuk Hakları İle İlgili Görüşleri, Yayınlanmamış Yüksek Lisans Tezi, Afyon Kocatepe Üniversitesi, Afyonkarahisar, 2011.

26. Kahriman İ, Topbas M, Can G, Göker Z, Deryal Y. Pediatrik Yaş Grubuna Sağlık Hizmeti Sunan Ebe Ve Hemşirelerin Çocuk Hasta Hakları Konusundaki Düşünceleri. Balıkesir Sağlık Bil Derg. 2016;5(1).

27. Uçuş Ş. Çocuk Hakları Sözleşmesi'nin İlköğretim Programlarındaki Yeri ve Sözleșmeye yönelik Öğretmenlerin ve Okul Yöneticilerin Görüşleri. Yüksek Lisans Tezi. Hacettepe Üniversitesi Sosyal Bilimler Enstitüsü İlköğretim Ana Bilim Dalı Sınıf Öğretmenliği Bilim Dalı. Ankara, 2009.

28. Fazıloğlu Z. Çocuk Hakları Sözlessmesi’nde Yer Alan “Çocuk Hakları” Konusunda Öğretmenlerin ve Yöneticilerin Bilinç Düzeyleri. Yüksek Lisans Tezi. Yeditepe Üniversitesi Sosyal Bilimler Enstitüsü. İstanbul, 2007

http://edergi.cbu.edu.tr/ojs/index.php/cbusbed isimli yazarın CBU-SBED baslıklı eseri bu Creative Commons Alıntı-Gayriticari4.0 Uluslararası Lisansı ile lisanslanmıştır. 